\title{
Clinical Evaluation of a Custom Gene Panel as a Tool for Precision Male Infertility Diagnosis by Next-Generation Sequencing
}

\author{
Rossella Cannarella ${ }^{1}\left(\mathbb{D}\right.$, Vincenza Precone $^{2}$, Giulia Guerri ${ }^{3}$, Gian Maria Busetto ${ }^{4}(\mathbb{D}$, \\ Gian Carlo Di Renzo ${ }^{5}$, Sandro Gerli ${ }^{5}\left(\mathbb{D}\right.$, Elena Manara ${ }^{2}\left(\mathbb{D}\right.$, Astrit Dautaj $^{6, *(D)}$, \\ Matteo Bertelli ${ }^{2,3,6}$ and Aldo Eugenio Calogero ${ }^{1}$ (D) \\ 1 Department of Clinical and Experimental Medicine, University of Catania, 95124 Catania, Italy; \\ rossella.cannarella@phd.unict.it (R.C.); acaloger@unict.it (A.E.C.) \\ 2 MAGI EUREGIO, 39100 Bolzano, Italy; vincenza_precone@yahoo.it (V.P.); \\ elena.manara@assomagi.org (E.M.); matteo.bertelli@assomagi.org (M.B.) \\ 3 MAGI'S LAB, 38068 Rovereto, Italy; giulia.guerri@assomagi.org \\ 4 Department of Urology, "Sapienza” University of Rome, Policlinico Umberto I, 00185 Rome, Italy; \\ gianmaria.busetto@uniroma1.it \\ 5 Department of Surgical and Biomedical Sciences, University of Perugia, 06123 Perugia, Italy; \\ giancarlo.direnzo@unipg.it (G.C.D.R.); sandro.gerli@unipg.it (S.G.) \\ 6 EBTNA-LAB, Via delle Maioliche, 57/G, 38068 Rovereto, Italy \\ * Correspondence: astrit.dautaj@assomagi.org
}

Received: 21 September 2020; Accepted: 12 October 2020; Published: 15 October 2020

check for updates

\begin{abstract}
Background: Up to $15 \%$ of couples are infertile and male factor infertility accounts for approximately $50 \%$ of these cases. Male infertility is a multifactorial pathological condition. The genetic of male infertility is very complex and at least 2000 genes are involved in its etiology. Genetic testing by next-generation sequencing (NGS) technologies can be relevant for its diagnostic value in male infertile patients. Therefore, the aim of this study was to implement the diagnostic offer with the use of an NGS panel for the identification of genetic variants. Methods: We developed an NGS gene panel that we used in 22 male infertile patients. The panel consisted of 110 genes exploring the genetic causes of male infertility; namely spermatogenesis failure due to single-gene mutations, central hypogonadism, androgen insensitivity syndrome, congenital hypopituitarism, and primary ciliary dyskinesia. Results: NGS and a subsequent sequencing of the positive pathogenic or likely pathogenic variants, 5 patients $(23 \%)$ were found to have a molecular defect. In particular, pathogenic variants were identified in TEX11, CCDC39, CHD7, and NR5A1 genes. Moreover, 14 variants of unknown significance and 7 novel variants were found that require further functional studies and family segregation. Conclusion: This extended NGS-based diagnostic approach may represent a useful tool for the diagnosis of male infertility. The development of a custom-made gene panel by NGS seems capable of reducing the proportion of male idiopathic infertility.
\end{abstract}

Keywords: male infertility; NGS diagnosis; defects of primary spermatogenesis; hypogonadotropic hypogonadism; primary ciliary dyskinesia

\section{Introduction}

It is estimated that about 48.5 million couples worldwide are affected by infertility [1-3]. Epidemiological data have addressed to the male factor an etiologic role, alone or in combination, in the half of cases of couple's infertility [4]. Genetic causes of male infertility, as well as the effects of their transmission to the offspring are still not fully understood [5]. The primary male infertility can 
be associated with abnormal semen or normal semen (idiopathic infertility). Instead, the secondary male infertility is due to systemic or syndromic genetic defects [6]. Disorders of sex development, ambiguous genitalia and androgen insensitivity, central hypogonadism, congenital hypopituitarism, and primary ciliary dyskinesia (PCD) can occur in syndromic forms [6-11]. Laboratory tests are of pivotal importance for a correct etiological classification of male infertility and for the choice of an effective treatment $[12,13]$. In addition to traditional first level diagnostic tests (seminal fluid analysis, hormone measurement, bacteriological analysis, and the search for anti-sperm antibodies), second level diagnostic tests such as sperm function tests and genetic analysis are useful for the assessment of male infertility [13]. In particular, genetic analysis is of relevance since about $15-30 \%$ of male infertility cases may recognize a genetic factor [14-16]. Genetic disorders related to male infertility include monogenic diseases and whole or partial chromosomal aberrations. Over 200 genetic conditions related to male infertility are reported in Online Mendelian Inheritance in Man (OMIM) database [17,18]. The identification of the genetic defect in the management of infertility allows also to establish the risk of its possible inheritance in preconception screening and the optimization of assisted fertilization techniques [19-21]. The genetic tests commonly used for male infertility diagnosis include karyotyping to detect numerical or structural abnormalities and PCR (polymerase chain reaction) to detect known genetic anomalies. However, it must be considered that the etiology remains elusive in about $40 \%$ of cases of male infertility (idiopathic forms) that, very likely, have a genetic unknown background [22,23]. Moreover, also it would be necessary to consider the role of recently discovered autosomal single-gene disorders in male infertility [24]. In fact, long been known chromosomal syndromes associated with infertility diagnosed by karyotype analysis, but only in recent years studies have been conducted on specific chromosomal regions and identified single genes linked to infertility problems. About $30 \%$ of infertility cases are still apparently sine causa and it is difficult for these to be syndromic conditions, but rather for conditions in which the reproductive defect is the only diagnostic indication $[25,26]$. Knowledge of the molecular defect attributable to single genes could lead to the development of targeted therapies to correct the genetic defect. The complexity of genetic tests for the diagnosis of infertility is continuously and rapidly growing thanks above all to the advent of new biomolecular and bioinformatics technologies. Within this scenario, the next-generation sequencing (NGS) technique can improve and personalize male infertility diagnosis. In addition, NGS can allow the simultaneous analysis of a large cohorts of infertile patients and the screening of multiple disease-causing variants of many genes [27]. The use of multigene panels can be a useful tool to improve the diagnostic framework of the patients $[21,27]$. Therefore, the aim of this study was to implement the diagnostic offer with the use of an NGS panel for the identification of genetic variants that may support a more accurate management of male infertility.

\section{Results}

Twenty-two male patients with infertility were analyzed with a NGS customized panel. Their median age was 37 years (range 19-56). The diagnostic suspects, made matching data coming from anamnesis, physical examination, hormone values, scrotal ultrasound, and/or sperm analysis, were primary spermatogenic defects $(n=16)$, central hypogonadism $(n=3)$, androgen insensitivity $(n=1)$, congenital hypopituitarism $(n=1)$, and primary ciliary dyskinesia $(n=1)$. For each patient, only the genes of the panel related to the diagnostic suspect were analyzed because the analysis was for diagnostic purposes. Genetic variants identified in the analyzed population by NGS are reported in Supplementary Table S1, whereas variants identified in the patients with a positive genetic diagnosis are reported in Table 1. 
Table 1. Variants identified in the patients with a positive genetic diagnosis.

\begin{tabular}{|c|c|c|c|c|c|c|c|c|c|c|}
\hline Case & Gene (Transcript Isoform) & Variant Position & Variant & Zygosity & SNP ID & Polyphen-2 & SIFT & Mutation Taster & MAF (\%) & Ref \\
\hline 1 & TEX11 (NM_001003811.1) & chrX:70554698 & $\begin{array}{l}\text { c.2288T > C; } \\
\text { p.Val763Ala }\end{array}$ & Hem & rs200139216 & Benign & Damaging & Polymorphism & $0.02 \%$ & [28] \\
\hline \multirow[t]{2}{*}{2} & CCDC39 (NM_181426.1) & chr3:180616671 & $\begin{array}{l}\text { c. } 2431 C>\text { T; } \\
\text { p.Arg811Cys }\end{array}$ & Het & rs574993914 & $\begin{array}{l}\text { Probably } \\
\text { damaging }\end{array}$ & Damaging & Disease-causing & $0.007 \%$ & l \\
\hline & & chr3:180659582 & c. $610-2 \mathrm{~A}>\mathrm{G}$ & Het & rs756235547 & 1 & 1 & Disease-causing & $0.01 \%$ & [29] \\
\hline 3 & CHD7 (NM_017780.3) & chr8:60821842 & $\begin{array}{l}\text { c. } 2750 \mathrm{C}>\mathrm{T} \text {; } \\
\text { p.Thr917Met }\end{array}$ & Het & rs1165711448 & $\begin{array}{l}\text { Probably } \\
\text { damaging }\end{array}$ & Damaging & Disease-causing & / & {$[30]$} \\
\hline 4 & NR5A1 (NM_004959.4) & chr9:124491167 & $\begin{array}{l}\text { c.1052C > T; } \\
\text { p.Ala351Val }\end{array}$ & Het & rs759071081 & $\begin{array}{l}\text { Probably } \\
\text { damaging }\end{array}$ & Tolerated & Disease-causing & $0.005 \%$ & {$[31]$} \\
\hline 5 & NR5A1 (NM_004959.4) & chr9:124491156 & $\begin{array}{l}\text { c.1063G > A; } \\
\text { p.Val355Met }\end{array}$ & Het & rs371701248 & $\begin{array}{l}\text { Probably } \\
\text { damaging }\end{array}$ & Damaging & Disease-causing & $0.01 \%$ & [31] \\
\hline
\end{tabular}


In clinical utility assessment, 5 patients (23\%) resulted positive for the diagnostic test.

\subsection{Case 1}

Case 1 was a 41-year-old patient, trying to reach fatherhood in the last 2 years. The female partner was 32 years old and no female factor infertility was found. Patient's physical examination was unremarkable, showing normal androgenization and no signs of genital malformation. Sperm analysis (which was performed according to the WHO 2010 criteria) showed oligoasthenozoospermia for three times. The mean (range) conventional sperm parameters were: $1.7(0.36-4)$ million $/ \mathrm{mL}$ for sperm concentration, 6.6 (2.5-14) million/ejaculate for total sperm count, 7 (3-10\%) for sperm progressive motility, 35.3 (20-56) for total sperm motility, 5.7 (3-10\%) for spermatozoa with normal form. Seminal fluid leukocytes were $<1 \mathrm{million} / \mathrm{mL}$ in all specimens. Follicle-stimulating hormone (FSH) serum values were $8.1 \mathrm{IU} / \mathrm{L}$. At scrotal ultrasound, testicular volumes were $14.7 \mathrm{~mL}$ and $14.1 \mathrm{~mL}$ for the right and the left testis, respectively. Male accessory gland infection, varicocele, or other acquired causes of male infertility were carefully assessed and could be excluded.

The patient was hence suspected of a defect of primary spermatogenic failure due to mutation in single genes. The analyzed sample showed the presence of two sequence alterations in the TEX11 gene located in the chromosome $X$, namely the pathogenic variant p.(Val763Ala) $(c .2288 \mathrm{~T}>\mathrm{C})$ (rs200139216) [28] and the likely benign variant p.(Thr259Ile) (c.776C > T) (rs762957753). In addition, it has also been identified in ZPBP (Zona Pellucida Binding Protein) gene the likely benign variant p.(Arg17Pro) (c.50G > C) (rs202231065) in heterozygosity. ZPBP gene ex:1 (chr7:50093185-50093209) was re-sequenced by Sanger (NGS coverage: 4,5X).

\subsection{Case 2}

Case 2 was a 19-year-old male patient suspected of having a primary ciliary dyskinesia. Physical examination showed normal androgenization, no genital malformation, normal penile size, and testicular volume, but the presence of right varicocele. At instrumental examination, he had dextrocardia and bronchiectasia. The patient was healthy and did not have respiratory symptoms. Sperm analysis documented azoospermia. After scleroembolization, he had oligoasthenoteratozoospermia. Transmission electronic microscopy analysis documented abnormal connecting piece and the absence of outer dynein arms in the sperm axoneme. It the respiratory cilia it showed abnormal number and position of peripheral microtubules and of central pair. The analyzed sample showed the presence of three sequence alterations in CCDC39 (Coiled-Coil Domain Containing 39) gene, namely the pathogenic variant c.610-2A > G (rs756235547) [29], a variant with uncertain pathogenic significance p.(Arg811Cys) (c.2431C > T) (rs574993914) and a variant probably benign p.(Thr182Ser) (c.545C > G) (rs112738198), all in heterozygosity. Moreover, it has also been identified in CDC151 gene a variant with uncertain pathogenic significance p.(Thr205Ile) (c.614C > T) (rs35061520) in heterozygosity detected by Sanger sequencing. However, since this gene is associated with a recessive inheritance, it is unlikely that this mutation alone could cause PCD.

\subsection{Case 3}

Case 3 was a 26-year-old male patient with reversal central hypogonadism. At the age of 14 years old, due to the absence of puberty, he underwent to genetic testing and pituitary imaging, revealing abnormally low gonadotropins (the pituitary function was normal for the other pituitary hormones) and the absence of abnormalities at imaging. He was then prescribed gonadotropins. At the age of 22 years, the patient reached a complete degree of androgenization. Withdrawal from treatment revealed the persistence of low gonadotropins and the diagnosis of central hypogonadism was confirmed. No abnormality of smell sense was referred by the patient. He was then prescribed testosterone replacement therapy (TRT). At the age of 24 years, TRT was discontinued. At hormone testing, gonadotropins were found within the normal range. At scrotal ultrasound, testicular volumes were $5.8 \mathrm{~mL}$ and $5 \mathrm{~mL}$, in the right and in the left testis, respectively. At the sperm analysis, 
a severe oligoasthenoteratozoospermia was found after 5 months from TRT withdrawal. Specifically, 5 spermatozoa in the whole specimen were found. None of them were motile and normally shaped. A severe left varicocele was found, and the patient was then counseled for scleroembolization.

At genetic testing, pathogenic variant p.(Thr917Met) $(c .2750 \mathrm{C}>\mathrm{T})(\mathrm{rs} 1165711448)$ of the CHD7 (Chromodomain-helicase-DNA-binding protein 7) gene was found [30]; it was confirmed by Sanger sequencing, and the variant with uncertain pathogenic significance p.(Ala369Val) c.1106C > T (rs771836971) in FLRT3 (Fibronectin Leucine Rich Transmembrane Protein 3) gene, both in heterozygosity.

\subsection{Case 4}

Case 4 was a 36-year-old male patient searching for fatherhood in the last 3 years. The female partner had a child from a previous marital relationship and a female factor infertility was excluded. Physical examination was unremarkable, with no sign of hypo-androgenization or genital malformation. FSH serum levels were $4.1 \mathrm{IU} / \mathrm{mL}$, luteinizing hormone (LH) $3.6 \mathrm{IU} / \mathrm{mL}$, and total testosterone $5.7 \mathrm{ng} / \mathrm{mL}$. At ultrasound, right and left testicular volumes were $14.1 \mathrm{~mL}$ and $14.9 \mathrm{~mL}$, respectively. The patient underwent sperm analysis for 4 time that showed oligozoospermia and teratozoospermia (mean sperm concentration 7.6 million/mL, mean total sperm count 21.5 million/ejaculate, sperm with normal morphology $3 \%$ ). Acquired causes of oligozoospermia were carefully excluded. The patient was then suspected of a defect of primary spermatogenic failure due to mutation in single genes. The pathogenic variant p.(Ala351Val) c.1052C > T (rs759071081) of the NR5A1 (Nuclear Receptor Subfamily 5 Group A Member 1) gene [31] was found in heterozygosity by NGS.

\subsection{Case 5}

Case 5 was a 39-year-old patient counseled for primary male infertility. His wife and he had searched for childhood in the last two years. The patient's wife was 35 years old and no female factor infertility was found. The physical examination of the patient was unremarkable, with normal androgenization and no sign of genital malformation. FSH serum levels were above the normal range $(17.5 \mathrm{IU} / \mathrm{mL})$ and, at ultrasound, the right and the left testicular volumes were $6.3 \mathrm{~mL}$ and $9.8 \mathrm{~mL}$, respectively, indicating testicular hypotrophy. Two sperm analyses showed $11.5 \mathrm{million} / \mathrm{mL}$ for sperm concentration, 11.5 million/ejaculate for total sperm count, $7.5 \%$ for progressive motility, $50 \%$ for total motility, and 5.5\% spermatozoa with normal morphology. These values indicated a diagnosis of oligoasthenozoospermia. After acquired causes were excluded, the patient underwent to genetic testing for the suspicious of primary spermatogenic failure due to mutation in single genes. The genetic test revealed the pathogenic variant in NR5A1 gene p.(Val355Met) (c.1063G > A) (rs371701248) [31] in heterozygosity and other two not pathogenic variants: p.(Arg323Cys) c.967C > T (rs764712886) in SEPT12 gene and p.(Ile2226Val) (c.6676A > G) (rs112505934) in DNAH1 gene. Interestingly, one year later, the patient spontaneously made his wife pregnant.

The coverage performance by NGS for these subjects is shown in Table 2. Coding genomic regions that were sequenced with a coverage less than 10X were eventually re-sequenced using Sanger technology.

Table 2. NGS Coverage performance for positive subjects of the diagnostic test.

\begin{tabular}{lcc}
\hline & Medium Coverage & Coverage $>\mathbf{1 0 X}$ \\
\hline Case 1 & $317.7 \mathrm{X}$ & $98.5 \%$ \\
Case 2 & $296.5 \mathrm{X}$ & $98.7 \%$ \\
Case 3 & $539.2 \mathrm{X}$ & $98.9 \%$ \\
Case 4 & $296.5 \mathrm{X}$ & $98.7 \%$ \\
Case 5 & $286.7 \mathrm{X}$ & $91.3 \%$ \\
\hline
\end{tabular}




\section{Discussion}

Male infertility can be the result of non-genetic or genetic factors, and it is often multifactorial and/or polygenic [32]. Hundreds of genes implicated in the development and function of the male reproductive system and in spermatogenesis can be involved [33]. Additional genetic anomalies contributing to male infertility are constantly identified. The process of evaluating the genes involved in male infertility is essential to optimize genetic testing in reproductive medicine and to implement the therapeutic management based on the specific genomic features of the patient. Interestingly, clinicians can more accurately decide whether male infertile patients are candidates for surgical retrieval of spermatozoa for use in assisted fertilization techniques by the knowledge of the nature of the genetic variants [34]. Studies of identification of relevant mutations and polymorphisms by NGS screening technologies can be used for this purpose and easily incorporated into the clinical practice. Moreover, NGS technologies have made it possible to compact one or more tests into a single NGS-based analysis, thus reducing diagnostic costs and time [35].

We have successfully developed a genetic test based on NGS that covers the main male infertility causes [25,36-38]. We have analyzed a custom-made panel of 110 genes in 22 infertile patients (Table 3). 
Table 3. Available clinical characteristics of all the analyzed patients. Abbreviations: FSH, follicle-stimulating hormone; ${ }^{*}$ evaluated with ultrasound; ${ }^{* *}$ values before therapy.

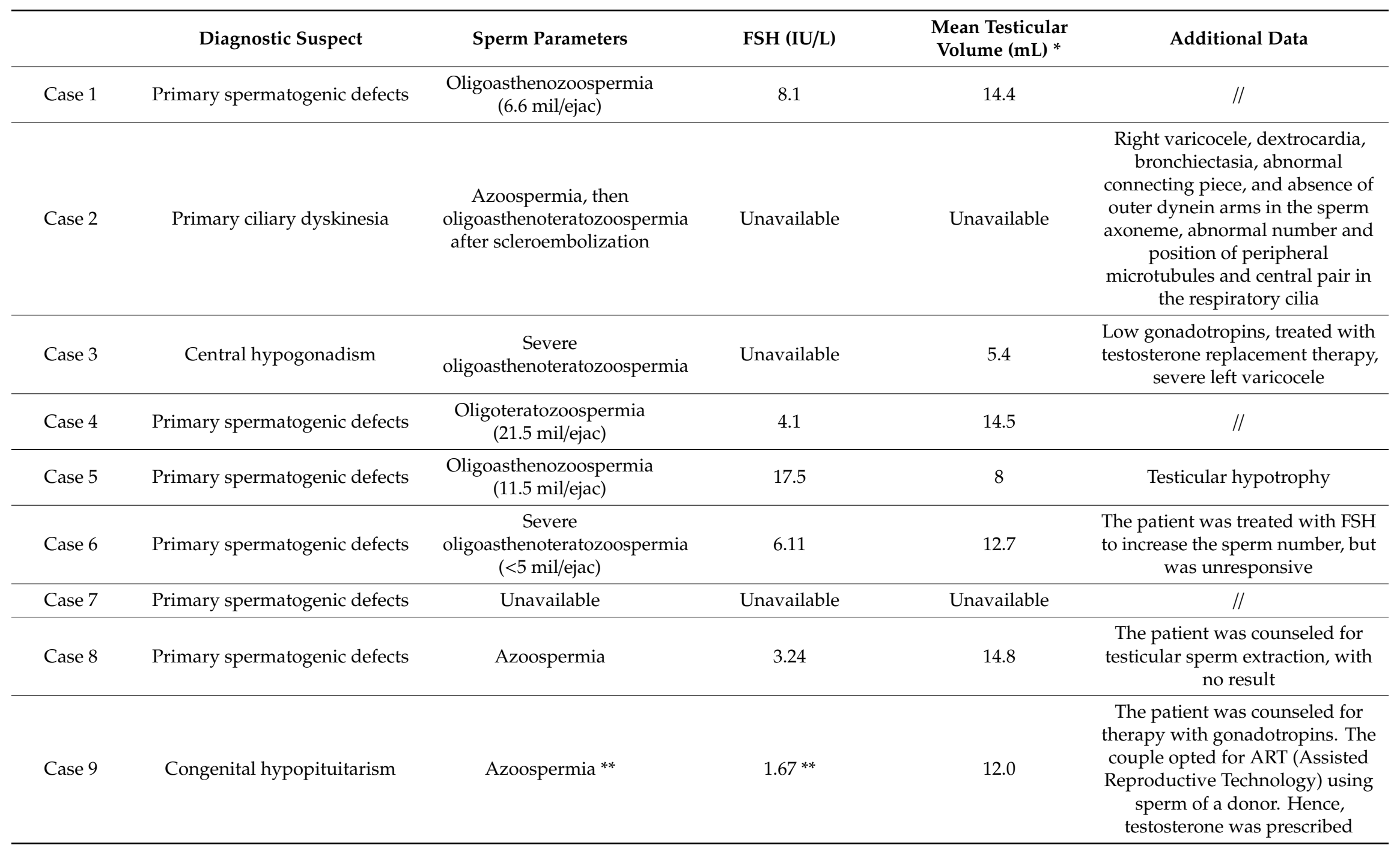


Table 3. Cont.

\begin{tabular}{|c|c|c|c|c|c|}
\hline & Diagnostic Suspect & Sperm Parameters & FSH (IU/L) & $\begin{array}{l}\text { Mean Testicular } \\
\text { Volume (mL) * }\end{array}$ & Additional Data \\
\hline Case 10 & Primary spermatogenic defects & Mild oligozoospermia & 3.77 & 11.6 & // \\
\hline Case 11 & Primary spermatogenic defects & Azoospermia & 30.9 & 6.6 & $\begin{array}{l}\text { Sertoli cell only syndrome was } \\
\text { found in testicular histology }\end{array}$ \\
\hline Case 12 & Central hypogonadism & Criptozoospermia ** & $<0.9^{* *}$ & 5.5 & $\begin{array}{l}\text { The patient was responsive to } \\
\text { treatment with gonadotropins }\end{array}$ \\
\hline Case 13 & Androgen insensitivity & Unavailable & Unavailable & Unavailable & $\begin{array}{c}\text { The patient had abnormally high } \\
\text { testosterone serum level. He has } \\
\text { normal androgenization }\end{array}$ \\
\hline Case 14 & Primary spermatogenic defects & $\begin{array}{c}\text { Severe } \\
\text { oligoasthenoteratozoospermia } \\
(<5 \text { mil/ejac })\end{array}$ & 2.14 & 8.0 & $/ /$ \\
\hline Case 15 & Primary spermatogenic defects & $\begin{array}{c}\text { Moderate } \\
\text { oligoasthenozoospermia } \\
(<15 \text { mil/ejac })\end{array}$ & 6.9 & 11.5 & $\begin{array}{c}\text { The patient was unresponsive to } \\
\text { treatment with FSH }\end{array}$ \\
\hline Case 16 & Primary spermatogenic defects & Unavailable & Unavailable & Unavailable & // \\
\hline Case 17 & Primary spermatogenic defects & Unavailable & Unavailable & Unavailable & $/ /$ \\
\hline Case 18 & Primary spermatogenic defects & Unavailable & Unavailable & Unavailable & $/ /$ \\
\hline Case 19 & Primary spermatogenic defects & Unavailable & Unavailable & Unavailable & $/ /$ \\
\hline Case 20 & Primary spermatogenic defects & Unavailable & Unavailable & Unavailable & $/ /$ \\
\hline Case 21 & Primary spermatogenic defects & Unavailable & Unavailable & Unavailable & // \\
\hline Case 22 & Primary spermatogenic defects & Unavailable & Unavailable & Unavailable & $/ /$ \\
\hline
\end{tabular}


Five of them with suspicion of primary spermatogenesis failure, central hypogonadism, and primary ciliary dyskinesia resulted positive at the diagnostic test. Five variants with a clearly known pathogenic role were identified in TEX11, CCDC39, CHD7, and NR5A1 genes. TEX11 (Testis-expressed gene 11), mapping on the Xq13.1 chromosome, is a X-linked gene essential for meiotic recombination and chromosomal synapsis expressed only in male germ cells [39,40]. The role of TEX11 in spermatogenesis has been recognized in knock-out mouse models and humans [28,41]. Currently, 47 TEX11 variants are known, including 25 variants in azoospermic male and 22 variants in fertile subjects [28]. CCDC39 (Coiled-Coil Domain-Containing 39), mapping on the chromosome 3q26.33, encodes for a protein involved in the motility of cilia and flagella. In particular, variations of CCDC39 gene cause defects in the assembly of the nexin-dynein regulatory complex and inner dynein arms, and disruption of this periodicity. Axonemal disorganization and inner dynein arm defects represent about $12 \%$ of all primary ciliary dyskinesia cases [42]. CHD7 is a gene, mapping on the 8q12.2 chromosome, associated with the CHARGE syndrome. It overlaps with Kallmann syndrome and central hypogonadism, since affects patients that show gonadotropin deficiency, showing that this gene is involved in puberty and reproduction [43]. Almost all de novo variants in CHD7 occur in the paternal germline [44,45]. Finally, NR5A1 (steroidogenic factor-1), a member of the nuclear receptor superfamily mapping on the chromosome 9q33.3, is a key transcriptional regulator of genes involved in the hypothalamic-pituitary-steroidogenic axis [46,47]. In mammalian testis determination and differentiation, NR5A1 is a positive regulator of SOX9 gene and anti-Müllerian hormone [48]. About 4\% of patients with otherwise unexplained severe spermatogenic failure carry variants in NR5A1 [49]. Variants of this gene are also a genetic cause of severer forms of male factor infertility, especially when associated with a history of cryptorchidism [50].

The pathogenic variants identified in these genes were reported in NCBI and their causal role has been shown by functional studies [29-32]. In particular, two of these variants in homozygosis were identified in TEX11 gene in case 1 (c.2288T $>C$ and c.776C $>\mathrm{T}$ ), of which one pathogenic and another likely benign. The pathogenic variant c.2288T $>\mathrm{C}$ identified in case 1 has been described in the literature in association with azoospermia with functional studies [29].

Three variants of CCDC39 gene in heterozygosity were identified in the case 2. The c.610-2A> G variant was considered pathogenic since it alters a splicing acceptor site and has already been reported in the literature associated with the subject's condition [29]. c.2431C > T variant was of uncertain pathogenic significance because it has not been reported in the literature in association with pathological phenotypes and it affects a conserved residue of the protein altering its nature. Finally, the CCDC39 c. $545 \mathrm{C}>\mathrm{G}$ variation was a benign variant.

Case 3 was found to be carrier of variants in CHD7 gene. The heterozygous variant c.2750C > in CHD7 is a missense variant in a gene region coding for a "critical" portion of the protein whose involvement has already been to be pathogenic $[30,36]$, and it is a variant considered "likely pathogenic" in most of the simulation programs selected for interpretive use. Other pathogenic variants were identified in NR5A1 gene that is notoriously involved in male infertility. In particular, 2 heterozygous variants in NR5A1 gene were found in two patients suspected of having a defect of primary spermatogenesis due to mutation in single genes: c.1052C $>\mathrm{T}$ in the case 4 and c.1063G $>\mathrm{A}$ in the case 5. Case 4 carried the c.1052C $>\mathrm{T}$ variant that affects a conserved residue of the protein located in a functional domain. This variant was reported in a patient with bilateral anorchia, in a functional study that demonstrates its reduced transcriptional activity. Furthermore, a segregation study showed that it was also present in the healthy relatives, suggesting a possible effect of incomplete penetrance [32]. Instead, the variation c.1063G > A identified in the case 5 affects a conserved protein residue but not altering its nature. It is in a functional domain of the protein and it has already been reported in the literature in a case of disorders of sexual development [31]. Noteworthy, a different variation of the same codon was reported in association with disorders of sexual development with male karyotype (sex reversal) with functional supporting studies that show that the variant alters a domain functional protein [51]. 
NGS-based genetic screening of a large panel of genes increases the number of novel variants and variants of uncertain pathogenic significance [52]. In this study, 4 splice variants (c.2316 + 1G > A in CATSPER1, c.1600-1G > A in DRC1, c.2427 + 1G > A in HFM1, c.325 + 2T > C in USP9Y) and 3 missense variants (c.2500A $>\mathrm{T}$ in $A R$, c.5805G > C in DNAH11 and c.907T > C in TUBB8) predicted in silico as probably deleterious were identified (ST1); however more data are needed to demonstrate their pathogenicity. Therefore, we did not report them in the results section. Surely, they warrant further studies in the future. Among variants with an uncertain pathogenic role, 14 with uncertain pathogenic significance were identified in this study. In the three positive cases, the variants with uncertain pathogenic significance c.776C $>\mathrm{T}$ in TEX1 and c.50G $>\mathrm{C}$ in $Z B P B, \mathrm{c} .2431 \mathrm{C}>\mathrm{T}$ in CCDC3 and c.614C $>\mathrm{T}$ in CDC151, c.1106C > T in FLRT3 were, respectively, identified. In other patients examined, c.6173C > T in DNAH11, c.1960C > T in DNAI1, c.854C > T in DNAI2, c.17G > A in PLK4 variants with uncertain pathogenic significance and c.2159G > A in GLI2 and c.1331C > T in LRRC6 variants with conflicting interpretations of pathogenicity were found. Although including variant of unknown significance (VUS) as decisive results of phenotype in routine clinical elective genetic testing is not recommended, it is recognized that clinical information provided with the sample may give significance to the VUS variants. Anyway, functional studies and segregation studies in other family members could shed light on the clinical significance of novel and with uncertain pathogenic significance variants. Other variants identified were very interesting but it is necessary a functional and segregation family study for these variants, for instance a frameshift variant c.3792_3793del (rs778085976) in CENPF, a stop lost variant c.417A > G (rs1429366684) in KISS1 and numerous splice variants (Supplementary Table S1). Because some cases of male infertility are due to unknown genetic variants, the detection of numerous genetic variants by NGS-based genetic screening is important to reduce the percentage of idiopathic infertility.

Genetic analysis is generally performed using many different platforms. The use of a NGS custom panel is advantageous because it allows the identification of variants by a single platform with optimal sensitivity and specificity. However, there are some limitations. For instance, the NGS custom-made panel cannot detect balanced translocations, which are known to cause infertility in $0.9 \%$ of patients and complex chromosomal rearrangements in infertile male patients [53,54]. Anyway, the NGS custom-made panel developed in this study had the ability to provide detailed information that help the clinical management of the infertile male.

In conclusion, our study showed the efficacy of an NGS-based approach in the diagnosis of male infertility according to the patient's clinical features. In fact, for patients with suspect and established diagnosis of male infertility obtained by first/second level diagnostic tests, it is of pivotal importance to use a genetic test in the attempt of explaining the underlying etiology of the disorder and guide the clinical management. Our gene panel solved the $22 \%$ (5/22) of cases considered with apparently idiopathic infertility. This is relevant since the prevalence of idiopathic male infertility has been esteemed as high as the $\sim 70 \%$ when panels currently available in the clinical practice are used [55]. Hence, the prevalence could be lower if properly tested with advanced gene panels.

In conclusion, for the patients with a negative diagnosis we could not determine the causative mutations and more studies are needed to evaluate whether the VUS we identified can have an effect on the observed phenotype or other genes should be investigated. Finally, it is not possible to establish phenotypic parameters that would suggest a genetic involvement. Therefore, it is useful to perform genetic testing in all idiopathic infertility cases, regardless of the severity.

\section{Materials and Methods}

\subsection{Patients and Blood Samples}

Twenty-two subjects with a clinical diagnosis of male infertility were selected for this study. All enrolled patients underwent pre-test counseling during which they were informed about the significance of molecular screening providing information about their personal and familial history, 
and informed consent was obtained from each subject. The study was conducted in accordance with the tenets of the Declaration of Helsinki and it was approved by the local Ethics Committee. A blood EDTA (Ethylenediaminetetraacetic acid) sample was collected from each subject. Samples of genomic DNA of all subjects were extracted from peripheral blood using a commercial kit (SAMAG 120 BLOOD DNA Extraction Kit, Como, Italy). DNA was quantified using Quant-iT Picogreen dsDNA Assay Kit (Invitrogen, Eugene, OR) and a Varioskan LUX (Thermo Scientific, Vantaa Finland).

\subsection{Gene Selection and Panel Design}

A NGS panel consisting of 110 diagnostic genes related to male infertility disorders was designed. The genes included in the panel were based on their correlation with male infertility described in OMIM [17], GeneReviews [56] and primary literature. For each subject, only the genes related to the diagnostic suspect were considered because the analysis was for diagnostic purposes. The custom Illumina Nextera panel included genomic targets comprising coding exons and $15 \mathrm{bp}$ flanking regions of each genes. The list of genes associated with male infertility included in the NGS panel broken down by diagnostic suspect is shown in Table 4 . The association of diagnostic suspects with their etiology is shown in the Supplementary Tables (ST2, ST3, ST4, ST5, ST6). The cumulative target length of the gene panel was $314,814 \mathrm{bp}$. For each diagnostic suspect the size target was respectively: $93,474 \mathrm{bp}$, $59,379 \mathrm{bp}, 3003 \mathrm{bp}, 12,729 \mathrm{bp}$ and 162,534 bp.

Table 4. Genes associated with male infertility included in the custom NGS panel.

\begin{tabular}{|c|c|c|c|c|c|c|}
\hline Male Condition & Location & Genes & OMIM \# & REFSEQ & Gene Name & $\begin{array}{l}\% \text { Target Bases with } \\
\text { Coverage } \geq 10 \mathrm{X}\end{array}$ \\
\hline \multirow{18}{*}{$\begin{array}{l}\text { Defects of primary } \\
\text { spermatogenesis }\end{array}$} & $19 q 13.43$ & AURKC & 603495 & NM_001015878 & aurora kinase $\mathrm{C}$ & $100.0 \%$ \\
\hline & 11q13.1 & CATSPER1 & 606389 & NM_053054 & $\begin{array}{l}\text { cation channel sperm } \\
\text { associated } 1\end{array}$ & $100.0 \%$ \\
\hline & $3 q 13.2$ & CFAP44 & 617559 & NM_018338 & $\begin{array}{c}\text { cilia and } \\
\text { flagella-associated } \\
\text { protein } 44\end{array}$ & $100.0 \%$ \\
\hline & $12 q 14.2$ & DPY19L2 & 613893 & NM_173812 & dpy-19 like 2 & $100.0 \%$ \\
\hline & $17 q 21.2$ & KLHL10 & 608778 & NM_152467 & $\begin{array}{l}\text { kelch like family } \\
\text { member } 10\end{array}$ & $100.0 \%$ \\
\hline & $10 q 26.11$ & NANOS1 & 608226 & NM_199461 & $\begin{array}{c}\text { nanos C2HC-type zinc } \\
\text { finger } 1\end{array}$ & $39.45 \%$ \\
\hline & 22q13.1 & PICK1 & 605926 & NM_012407 & $\begin{array}{l}\text { protein interacting with } \\
\text { PRKCA } 1\end{array}$ & $99.75 \%$ \\
\hline & $4 q 28.1$ & PLK4 & 605031 & NM_014264 & polo like kinase 4 & $100.0 \%$ \\
\hline & $16 \mathrm{p} 13.3$ & SEPTIN12 & 611562 & NM_144605 & septin 12 & $100.0 \%$ \\
\hline & $9 q 34.3$ & SOHLH1 & 610224 & NM_001012415 & $\begin{array}{l}\text { spermatogenesis and } \\
\text { oogenesis-specific basic } \\
\text { helix-loop-helix } 1\end{array}$ & $100.0 \%$ \\
\hline & $20 \mathrm{q} 11.21$ & SUN5 & 613942 & NM_080675 & $\begin{array}{c}\text { Sad1 and UNC84 } \\
\text { domain-containing } 5\end{array}$ & $85.74 \%$ \\
\hline & $12 q 23.2$ & SYCP3 & 604759 & NM_001177948 & $\begin{array}{c}\text { synaptonemal complex } \\
\text { protein } 3\end{array}$ & $99.69 \%$ \\
\hline & Xp11 & TEX11 & 300311 & NM_001003811 & testis-expressed 11 & $96.43 \%$ \\
\hline & Yq11.221 & USP9Y & 400005 & NM_004654 & $\begin{array}{l}\text { ubiquitin specific } \\
\text { peptidase } 9 \text { Y-linked }\end{array}$ & $99.8 \%$ \\
\hline & $7 \mathrm{p} 12.2$ & $Z P B P$ & 608498 & NM_007009 & $\begin{array}{l}\text { zona pellucida binding } \\
\text { protein }\end{array}$ & $98.08 \%$ \\
\hline & $1 \mathrm{p} 22.1$ & $B R D T$ & 602144 & NM_001726 & $\begin{array}{l}\text { bromodomain } \\
\text { testis-associated }\end{array}$ & $100.0 \%$ \\
\hline & $10 q 25.1$ & CFAP43 & 617558 & NM_025145 & $\begin{array}{c}\text { cilia and } \\
\text { flagella-associated } \\
\text { protein } 43\end{array}$ & $98.45 \%$ \\
\hline & $3 p 21.1$ & DNAH1 & 603332 & NM_015512 & $\begin{array}{c}\text { dynein axonemal heavy } \\
\text { chain } 1\end{array}$ & $100.0 \%$ \\
\hline
\end{tabular}


Table 4. Cont.

\begin{tabular}{|c|c|c|c|c|c|c|}
\hline \multirow[t]{10}{*}{ Male Condition } & Location & Genes & OMIM \# & REFSEQ & Gene Name & $\begin{array}{l}\% \text { Target Bases with } \\
\text { Coverage } \geq 10 \mathrm{X}\end{array}$ \\
\hline & $6 q 22.31$ & HSF2 & 140581 & NM_004506 & $\begin{array}{l}\text { heat shock transcription } \\
\text { factor } 2\end{array}$ & $100.0 \%$ \\
\hline & 16 p13.3 & MEIOB & 617670 & NM_152764 & $\begin{array}{l}\text { meiosis specific with } \\
\text { OB-fold }\end{array}$ & $100.0 \%$ \\
\hline & $9 q 33.3$ & NR5A1 & 184757 & NM_004959 & $\begin{array}{c}\text { nuclear receptor } \\
\text { subfamily } 5 \text { group A } \\
\text { member } 1\end{array}$ & $100.0 \%$ \\
\hline & $12 \mathrm{p} 12.3$ & PLCZ1 & 608075 & NM_033123 & phospholipase C zeta 1 & $100.0 \%$ \\
\hline & $\mathrm{Xq} 24$ & RHOXF2 & 300447 & NM_032498 & $\begin{array}{l}\text { Rhox homeobox family } \\
\text { member } 2\end{array}$ & $95.41 \%$ \\
\hline & $6 \mathrm{p} 21.31$ & SLC26A8 & 608480 & NM_052961 & $\begin{array}{l}\text { solute carrier family } 26 \\
\text { member } 8\end{array}$ & $100.0 \%$ \\
\hline & $3 q 26.31$ & SPATA16 & 609856 & NM_031955 & $\begin{array}{l}\text { spermatogenesis } \\
\text { associated } 16\end{array}$ & $100.0 \%$ \\
\hline & $10 \mathrm{q} 26.3$ & SYCE1 & 611486 & NM_130784 & $\begin{array}{c}\text { synaptonemal complex } \\
\text { central element protein } \\
1\end{array}$ & $100.0 \%$ \\
\hline & $18 \mathrm{q} 11.2$ & TAF4B & 601689 & NM_005640 & $\begin{array}{l}\text { TATA-box binding } \\
\text { protein-associated } \\
\text { factor } 4 \mathrm{~b}\end{array}$ & $98.17 \%$ \\
\hline \multirow{20}{*}{$\begin{array}{l}\text { Hypogonadotropic } \\
\text { hypogonadism }\end{array}$} & 8p12 & TEX15 & 605795 & NM_001350162 & $\begin{array}{l}\text { testis-expressed 15, } \\
\text { meiosis, and } \\
\text { synapsis-associated }\end{array}$ & $100.0 \%$ \\
\hline & 17p13.2 & ZMYND15 & 614312 & NM_001136046 & $\begin{array}{l}\text { zinc finger MYND-type } \\
\text { containing } 15\end{array}$ & $92.29 \%$ \\
\hline & Xp22.31 & ANOS1 & 300836 & NM_000216 & anosmin 1 & $95.4 \%$ \\
\hline & $2 q 31.2$ & CCDC141 & 616031 & NM_173648 & $\begin{array}{c}\text { coiled-coil } \\
\text { domain-containing } 141\end{array}$ & $99.89 \%$ \\
\hline & $12 q 21.33$ & DUSP6 & 602748 & NM_001946 & $\begin{array}{l}\text { dual specificity } \\
\text { phosphatase } 6\end{array}$ & $100.0 \%$ \\
\hline & $8 \mathrm{p} 21.3$ & FGF17 & 603725 & NM_003867 & $\begin{array}{l}\text { fibroblast growth factor } \\
17\end{array}$ & $100.0 \%$ \\
\hline & $8 p 11.23$ & FGFR1 & 136350 & NM_023110 & $\begin{array}{l}\text { fibroblast growth factor } \\
\text { receptor } 1\end{array}$ & $100.0 \%$ \\
\hline & 11p14.1 & FSHB & 136530 & NM_000510 & $\begin{array}{c}\text { follicle-stimulating } \\
\text { hormone subunit beta }\end{array}$ & $100.0 \%$ \\
\hline & $4 q 13.2$ & GNRHR & 138850 & NM_000406 & $\begin{array}{c}\text { gonadotropin-releasing } \\
\text { hormone receptor }\end{array}$ & $100.0 \%$ \\
\hline & $3 p 14.3$ & $I L 17 R D$ & 606807 & NM_017563 & $\begin{array}{c}\text { interleukin } 17 \text { receptor } \\
\text { D }\end{array}$ & $100.0 \%$ \\
\hline & $19 \mathrm{p} 13.3$ & KISS1R & 604161 & NM_032551 & KISS1 receptor & $84.84 \%$ \\
\hline & $9 q 34.3$ & NSMF & 608137 & NM_015537 & $\begin{array}{c}\text { NMDA receptor } \\
\text { synaptonuclear } \\
\text { signaling and neuronal } \\
\text { migration factor }\end{array}$ & $95.03 \%$ \\
\hline & $3 p 13$ & PROK2 & 607002 & NM_021935 & prokineticin 2 & $97.67 \%$ \\
\hline & 7q21.11 & $S E M A 3 A$ & 603961 & NM_006080 & semaphorin 3A & $100.0 \%$ \\
\hline & $9 q 34.3$ & SOHLH1 & 610224 & NM_001012415 & $\begin{array}{l}\text { spermatogenesis and } \\
\text { oogenesis-specific basic } \\
\text { helix-loop-helix } 1\end{array}$ & $100.0 \%$ \\
\hline & $5 q 31.3$ & SPRY4 & 607984 & NM_030964 & $\begin{array}{l}\text { sprouty RTK-signaling } \\
\text { antagonist } 4\end{array}$ & $98.25 \%$ \\
\hline & $5 q 31.3$ & $S R A 1$ & 603819 & NM_001035235 & $\begin{array}{c}\text { steroid receptor RNA } \\
\text { activator } 1\end{array}$ & $100.0 \%$ \\
\hline & $4 q 24$ & TACR3 & 162332 & NM_001059 & tachykinin receptor 3 & $100.0 \%$ \\
\hline & $19 \mathrm{q} 13.2$ & $A X L$ & 109135 & NM_021913 & $\begin{array}{l}\text { AXL receptor tyrosine } \\
\text { kinase }\end{array}$ & $100.0 \%$ \\
\hline & $8 \mathrm{q} 12.2$ & CHD7 & 608892 & NM_017780 & $\begin{array}{l}\text { chromodomain helicase } \\
\text { DNA binding protein } 7\end{array}$ & $99.54 \%$ \\
\hline
\end{tabular}


Table 4. Cont.

\begin{tabular}{|c|c|c|c|c|c|c|}
\hline Male Condition & Location & Genes & OMIM \# & REFSEQ & Gene Name & $\begin{array}{l}\% \text { Target Bases with } \\
\text { Coverage } \geq 10 \mathrm{X}\end{array}$ \\
\hline & $7 \mathrm{q} 31.32$ & FEZF1 & 613301 & NM_001024613 & FEZ family zinc finger 1 & $96.46 \%$ \\
\hline & $10 \mathrm{q} 24.32$ & FGF8 & 600483 & NM_033163 & $\begin{array}{l}\text { fibroblast growth } \\
\text { factor } 8\end{array}$ & $93.16 \%$ \\
\hline & 20p12.1 & FLRT3 & 604808 & NM_198391 & $\begin{array}{l}\text { fibronectin leucine rich } \\
\text { transmembrane } \\
\text { protein } 3\end{array}$ & $100.0 \%$ \\
\hline & $8 \mathrm{p} 21.2$ & GNRH1 & 152760 & NM_001083111 & $\begin{array}{l}\text { gonadotropin-releasing } \\
\text { hormone } 1\end{array}$ & $100.0 \%$ \\
\hline & $2 \mathrm{q} 14.3$ & HS6ST1 & 604846 & NM_004807 & $\begin{array}{c}\text { heparan sulfate } \\
\text { 6-O-sulfotransferase } 1\end{array}$ & $96.3 \%$ \\
\hline & $1 \mathrm{q} 32.1$ & KISS1 & 603286 & NM_002256 & $\begin{array}{l}\text { KiSS-1 metastasis } \\
\text { suppressor }\end{array}$ & $100.0 \%$ \\
\hline & $19 \mathrm{q} 13.33$ & LHB & 152780 & NM_000894 & $\begin{array}{l}\text { luteinizing hormone } \\
\text { subunit beta }\end{array}$ & $100.0 \%$ \\
\hline & 20p12.3 & PROKR2 & 607123 & NM_144773 & prokineticin receptor 2 & $100.0 \%$ \\
\hline & 7q21.11 & SEMA3E & 608166 & NM_012431 & semaphorin 3E & $100.0 \%$ \\
\hline & 22q13.1 & SOX10 & 602229 & NM_006941 & $\begin{array}{l}\text { SRY-box transcription } \\
\text { factor } 10\end{array}$ & $100.0 \%$ \\
\hline & 12q13.3 & TAC3 & 162330 & NM_013251 & tachykinin precursor 3 & $100.0 \%$ \\
\hline & $10 \mathrm{q} 26.12$ & WDR11 & 606417 & NM_018117 & WD repeat domain 11 & $100.0 \%$ \\
\hline $\begin{array}{l}\text { Androgen } \\
\text { insensitivity }\end{array}$ & Xq12 & $A R$ & 313700 & NM_000044 & androgen receptor & $100.0 \%$ \\
\hline \multirow{8}{*}{$\begin{array}{c}\text { Congenital } \\
\text { hypopituitarism }\end{array}$} & $2 \mathrm{q} 14.2$ & GLI2 & 165230 & NM_005270 & GLI family zinc finger 2 & $91.92 \%$ \\
\hline & $9 q 34.3$ & LHX3 & 600577 & NM_014564 & LIM homeobox 3 & $81.51 \%$ \\
\hline & $14 \mathrm{q} 22.3$ & OTX2 & 600037 & NM_172337 & $\begin{array}{l}\text { orthodenticle } \\
\text { homeobox } 2\end{array}$ & $100.0 \%$ \\
\hline & $5 q 35.3$ & PROP1 & 601538 & NM_006261 & $\begin{array}{l}\text { PROP paired-like } \\
\text { homeobox } 1\end{array}$ & $95.99 \%$ \\
\hline & $3 p 14.3$ & HESX1 & 601802 & NM_003865 & HESX homeobox 1 & $100.0 \%$ \\
\hline & $1 \mathrm{q} 25.2$ & LHX4 & 602146 & NM_033343 & LIM homeobox 4 & $100.0 \%$ \\
\hline & $3 p 11.2$ & POU1F1 & 173110 & NM_000306 & $\begin{array}{l}\text { POU class } 1 \\
\text { homeobox } 1\end{array}$ & $100.0 \%$ \\
\hline & Xq27.1 & SOX3 & 313430 & NM_005634 & $\begin{array}{l}\text { SRY-box transcription } \\
\text { factor } 3\end{array}$ & $70.12 \%$ \\
\hline \multirow{12}{*}{$\begin{array}{l}\text { Primary ciliary } \\
\text { dyskinesia }\end{array}$} & 10p12.1 & $A R M C 4$ & 615408 & NM_001290020 & $\begin{array}{l}\text { armadillo } \\
\text { repeat-containing } 4\end{array}$ & $99.65 \%$ \\
\hline & $17 q 21.31$ & CCDC103 & 614677 & NM_213607 & $\begin{array}{c}\text { coiled-coil } \\
\text { domain-containing } 103\end{array}$ & $100.0 \%$ \\
\hline & 19p13.2 & $C C D C 151$ & 615956 & NM_145045 & $\begin{array}{c}\text { coiled-coil } \\
\text { domain-containing } 151\end{array}$ & $99.13 \%$ \\
\hline & 17q25.3 & $C C D C 40$ & 613799 & NM_017950 & $\begin{array}{c}\text { coiled-coil } \\
\text { domain-containing } 40\end{array}$ & $98.52 \%$ \\
\hline & $5 q 11.2$ & $\mathrm{CCNO}$ & 607752 & NM_021147 & cyclin $\mathrm{O}$ & $100.0 \%$ \\
\hline & $21 \mathrm{q} 22.11$ & CFAP298 & 615494 & NM_021254 & $\begin{array}{c}\text { cilia and } \\
\text { flagella-associated } \\
\text { protein } 298 \\
\end{array}$ & $100.0 \%$ \\
\hline & $14 \mathrm{q} 21.3$ & $D N A A F 2$ & 612517 & NM_018139 & $\begin{array}{l}\text { dynein axonemal } \\
\text { assembly factor } 2\end{array}$ & $95.63 \%$ \\
\hline & 19q13.42 & $D N A A F 3$ & 614566 & NM_178837 & $\begin{array}{l}\text { dynein axonemal } \\
\text { assembly factor } 3\end{array}$ & $89.24 \%$ \\
\hline & $7 \mathrm{p} 22.3$ & $D N A A F 5$ & 614864 & NM_017802 & $\begin{array}{l}\text { dynein axonemal } \\
\text { assembly factor } 5\end{array}$ & $78.93 \%$ \\
\hline & 7p15.3 & DNAH11 & 603339 & NM_001277115 & $\begin{array}{l}\text { dynein axonemal heavy } \\
\text { chain } 11\end{array}$ & $99.94 \%$ \\
\hline & $6 \mathrm{p} 21.2$ & DNAH8 & 603337 & NM_001206927 & $\begin{array}{l}\text { dynein axonemal heavy } \\
\text { chain } 8\end{array}$ & $99.93 \%$ \\
\hline & $17 q 25.1$ & DNAI2 & 605483 & NM_023036 & $\begin{array}{c}\text { dynein axonemal } \\
\text { intermediate chain } 2\end{array}$ & $100.0 \%$ \\
\hline
\end{tabular}


Table 4. Cont.

\begin{tabular}{|c|c|c|c|c|c|c|}
\hline Male Condition & Location & Genes & OMIM \# & REFSEQ & Gene Name & $\begin{array}{l}\% \text { Target Bases with } \\
\text { Coverage } \geq 10 \mathrm{X}\end{array}$ \\
\hline & $14 \mathrm{q} 24.3$ & DNAL1 & 610062 & NM_031427 & $\begin{array}{c}\text { dynein axonemal light } \\
\text { chain } 1\end{array}$ & $100.0 \%$ \\
\hline & $16 \mathrm{q} 24.3$ & GAS8 & 605178 & NM_001481 & growth arrest specific 8 & $98.09 \%$ \\
\hline & $8 \mathrm{q} 24.22$ & LRRC6 & 614930 & NM_012472 & $\begin{array}{c}\text { leucine rich } \\
\text { repeat-containing } 6\end{array}$ & $100.0 \%$ \\
\hline & $7 \mathrm{p} 14.1$ & NME8 & 607421 & NM_016616 & $\begin{array}{l}\text { NME/NM23 family } \\
\text { member } 8\end{array}$ & $100.0 \%$ \\
\hline & $21 \mathrm{q} 22.3$ & RSPH1 & 609314 & NM_080860 & $\begin{array}{l}\text { radial spoke head } \\
\text { component } 1\end{array}$ & $100.0 \%$ \\
\hline & $6 \mathrm{q} 22.1$ & RSPH4A & 612647 & NM_001010892 & $\begin{array}{l}\text { radial spoke head } \\
\text { component } 4 \mathrm{~A}\end{array}$ & $100.0 \%$ \\
\hline & $8 \mathrm{q} 22.2$ & SPAG1 & 603395 & NM_172218 & $\begin{array}{l}\text { sperm associated } \\
\text { antigen } 1\end{array}$ & $94.7 \%$ \\
\hline & $17 q 21.2$ & TTC25 & 617095 & NM_031421 & $\begin{array}{l}\text { tetratricopeptide repeat } \\
\text { domain } 25\end{array}$ & $90.46 \%$ \\
\hline & $3 p 14.2$ & CFAP20DC & 300572 & NM_198463 & $\begin{array}{c}\text { CFAP20 } \\
\text { domain-containing }\end{array}$ & $100.0 \%$ \\
\hline & $19 q 13.33$ & CCDC114 & 615038 & NM_144577 & $\begin{array}{c}\text { coiled-coil } \\
\text { domain-containing } 114\end{array}$ & $100.0 \%$ \\
\hline & $3 q 26.33$ & CCDC39 & 613798 & NM_181426 & $\begin{array}{c}\text { coiled-coil } \\
\text { domain-containing } 39\end{array}$ & $100.0 \%$ \\
\hline & $12 \mathrm{q} 13.12$ & CCDC65 & 611088 & NM_033124 & $\begin{array}{c}\text { coiled-coil } \\
\text { domain-containing } 65\end{array}$ & $100.0 \%$ \\
\hline & $1 \mathrm{q} 41$ & CENPF & 600236 & NM_016343 & centromere protein $\mathrm{F}$ & $100.0 \%$ \\
\hline & $16 \mathrm{q} 24.1$ & $D N A A F 1$ & 613190 & NM_178452 & $\begin{array}{l}\text { dynein axonemal } \\
\text { assembly factor } 1\end{array}$ & $100.0 \%$ \\
\hline & $15 q 21.3$ & $D N A A F 4$ & 608706 & NM_130810 & $\begin{array}{l}\text { dynein axonemal } \\
\text { assembly factor } 4\end{array}$ & $100.0 \%$ \\
\hline & $3 p 21.1$ & DNAH1 & 603332 & NM_015512 & $\begin{array}{c}\text { dynein axonemal heavy } \\
\text { chain } 1\end{array}$ & $100.0 \%$ \\
\hline & $5 p 15.2$ & DNAH5 & 603335 & NM_001369 & $\begin{array}{c}\text { dynein axonemal heavy } \\
\text { chain } 5\end{array}$ & $99.82 \%$ \\
\hline & $9 \mathrm{p} 13.3$ & DNAI1 & 604366 & NM_012144 & $\begin{array}{c}\text { dynein axonemal } \\
\text { intermediate chain } 1\end{array}$ & $100.0 \%$ \\
\hline & 11q13.4 & DNAJB13 & 610263 & NM_153614 & $\begin{array}{l}\text { DnaJ heat shock protein } \\
\text { family (Hsp40) member } \\
\text { B13 }\end{array}$ & $100.0 \%$ \\
\hline & $2 \mathrm{p} 23.3$ & DRC1 & 615288 & NM_145038 & $\begin{array}{l}\text { dynein regulatory } \\
\text { complex subunit } 1\end{array}$ & $93.24 \%$ \\
\hline & $16 \mathrm{q} 22.2$ & HYDIN & 610812 & NM_001270974 & $\begin{array}{l}\text { HYDIN axonemal } \\
\text { central pair apparatus } \\
\text { protein }\end{array}$ & $98.92 \%$ \\
\hline & $5 q 11.2$ & MCIDAS & 614086 & NM_001190787 & $\begin{array}{c}\text { multiciliate } \\
\text { differentiation and } \\
\text { DNA synthesis } \\
\text { associated cell cycle } \\
\text { protein }\end{array}$ & $100.0 \%$ \\
\hline & $\mathrm{Xq} 22.3$ & $D N A A F 6$ & 300933 & NM_001169154 & $\begin{array}{l}\text { dynein axonemal } \\
\text { assembly factor } 6\end{array}$ & $100.0 \%$ \\
\hline & $6 q 25.3$ & RSPH3 & 615876 & NM_031924 & radial spoke head 3 & $100.0 \%$ \\
\hline & $6 \mathrm{p} 21.1$ & RSPH9 & 612648 & NM_152732 & $\begin{array}{l}\text { radial spoke head } \\
\text { component } 9\end{array}$ & $100.0 \%$ \\
\hline & $2 q 35$ & STK36 & 607652 & NM_015690 & $\begin{array}{l}\text { serine/threonine } \\
\text { kinase } 36\end{array}$ & $100.0 \%$ \\
\hline & $3 p 21.31$ & ZMYND10 & 607070 & NM_015896 & $\begin{array}{c}\text { zinc finger } \\
\text { MYND-type-containing } 10\end{array}$ & $100.0 \%$ \\
\hline
\end{tabular}




\subsection{Genetic Analysis and Variant Detection}

DNA samples were processed for library preparation targeted capture and sequencing as previous reported $[57,58]$. In particular, $150 \mathrm{bp}$ paired-end reads sequencing was performed on MiSeq personal sequencer (Illumina, San Diego, CA) according to the manufacturer's instructions. Fastq (forward-reverse) files were obtained after sequencing. Reads alignment was done by the BWA (0.7.17-r1188) software. Duplicates were removed using the SAMBAMBA (0.6.7) program and GATK (4.0.0.0) were used for re-alignment. We used international databases dbSNP (www.ncbi. nlm.nih.gov/SNP/) and Human Gene Mutation Database professional (HGMD; http://www.biobase international.com/product/hgmd) for all nucleotide changes. In silico evaluation of the pathogenicity of nucleotide changes in exons was performed using PolyPhen-2 (http://genetics.bwh.harvard.edu/ pph2/), SIFT (https://sift.bii.a-star.edu.sg/), and Mutation Taster (http://www. mutationtaster.org). Minor allele frequencies (MAF) were checked in the Genome Aggregation Database (gnomAD (http://gnomad.broadinstitute.org/)). Sanger sequencing was performed for confirmation when target region coverage was less than 10 reads. Nucleotide alterations were analyzed and validated by Sanger sequencing. After confirmation, each variant was classified as pathogenic, likely pathogenic, VUS, likely benign, or benign, in according to the American College of Medical Genetics (ACMG) guidelines [59]. Variants were considered causative when at least 2 predictors evaluated the variants as damaging and/or there were literature data that demonstrated the pathogenicity.

Supplementary Materials: The following are available online at http:/www.mdpi.com/2075-1729/10/10/242/s1, Table S1: Genetic variants identified in the analysed population by NGS. ${ }^{1}$ All identified variants are indicated both by cDNA base sequence (third column) and by protein sequence (fourth column) according to the HGVS (Human Genome Variation Society) nomenclature guidelines. ${ }^{2}$ Information reported in NCBI (National Centre for Biotechnology Information) database, Table S2: List of defects of primary spermatogenesis due to mutation in single genes and their genetic etiology, Table S3: List of hypogonadotropic hypogonadism and their genetic etiology, Table S4: List of primary ciliary dyskinesia and their genetic etiology, Table S5: List of androgen insensitivity and their genetic etiology, Table S6: List of congenital hypopituitarism and their genetic etiology.

Author Contributions: Conceptualization, M.B. and A.E.C.; Data curation, R.C., V.P., G.G., G.M.B., G.C.D.R., S.G., E.M., A.E.C., A.D.; methodology, G.G.; Investigation, V.P., R.C.; Writing—original draft, V.P.; Funding acquisition, M.B. Project administration, M.B. All authors have read and agreed to the published version of the manuscript.

Funding: This work was supported by funding from the Provincia Autonoma di Trento within the initiative LP6/99 (dpg 1045/2017).

Conflicts of Interest: The authors declare no conflict of interest.

\section{References}

1. Pereira, R.; Sá, R.; Barros, A.; Sousa, M. Major regulatory mechanisms involved in sperm motility. Asian J. Androl. 2015, 19, 5-14. [CrossRef] [PubMed]

2. Vanaken, G.J.; Bassinet, L.; Boon, M.; Mani, R.; Honoré, I.; Papon, J.-F.; Cuppens, H.; Jaspers, M.; Lorent, N.; Coste, A.; et al. Infertility in an adult cohort with primary ciliary dyskinesia: Phenotype-gene association. Eur. Respir. J. 2017, 50, 1700314. [CrossRef] [PubMed]

3. Pereira, R.; Oliveira, M.E.; Santos, R.; Oliveira, E.; Barbosa, T.; Santos, T.; Gonçalves, P.; Ferraz, L.; Pinto, S.; Barros, A.; et al. Characterization of CCDC103 expression profiles: Further insights in primary ciliary dyskinesia and in human reproduction. J. Assist. Reprod. Genet. 2019, 36, 1683-1700. [CrossRef] [PubMed]

4. Shu, J.-H.; Feng, G.; Li, J.; Li, J.-X.; Gan, X.-Y.; Zhang, B.; Zhou, H.; Liu, Y. Predictive value of sperm morphology according to WHO Laboratory Manual for the Examination and Processing of Human Semen (5th Ed) on the outcomes of IVF-ET. Zhonghua nan ke xue Natl. J. Androl. 2013, 19, 414-417.

5. Coutton, C.; Fissore, R.A.; Palermo, G.D.; Stouffs, K.; Touré, A. Male Infertility: Genetics, Mechanism, and Therapies. BioMed Res. Int. 2016, 2016, 7372362. [CrossRef]

6. Zorrilla, M.; Yatsenko, A.N. The Genetics of Infertility: Current Status of the Field. Curr. Genet. Med. Rep. 2013, 1, 247-260. [CrossRef]

7. Matzuk, M.M.; Lamb, D.J. The biology of infertility: Research advances and clinical challenges. Nat. Med. 2008, 14, 1197-1213. [CrossRef] 
8. Semple, R.K.; Topaloglu, A.K. The recent genetics of hypogonadotrophic hypogonadism-novel insights and new questions. Clin. Endocrinol. 2010, 72, 427-435. [CrossRef]

9. McPhaul, M.J.; Marcelli, M.; Zoppi, S.; Wilson, C.M.; Griffin, J.E.; Wilson, J.D. Mutations in the ligand-binding domain of the androgen receptor gene cluster in two regions of the gene. J. Clin. Investig. 1992, 90, 2097-2101. [CrossRef]

10. Damseh, N.; Quercia, N.; Rumman, N.; Dell, S.D.; Kim, R.H. Primary ciliary dyskinesia: Mechanisms and management. Appl. Clin. Genet. 2017, 10, 67-74. [CrossRef]

11. Parks, J.S. Congenital Hypopituitarism. Clin. Perinatol. 2018, 45, 75-91. [CrossRef] [PubMed]

12. Forti, G.; Krausz, C. Clinical review 100: Evaluation and treatment of the infertile couple. J. Clin. Endocrinol. Metab. 1998, 83, 4177-4188. [PubMed]

13. Sikka, S.C.; Hellstrom, W.J. Current updates on laboratory techniques for the diagnosis of male reproductive failure. Asian, J. Androl. 2016, 18, 392-401. [CrossRef] [PubMed]

14. Xavier, M.J.; Salas-Huetos, A.; Oud, M.S.; Aston, K.I.; Veltman, J.A. Disease gene discovery in male infertility: Past, present and future. Qual. Life Res. 2020, 1-13. [CrossRef]

15. Cannarella, R.; Condorelli, R.A.; Paolacci, S.; Barbagallo, F.; Guerri, G.; Bertelli, M.; La Vignera, S.; Calogero, A.E. Next-generation sequencing: Toward an increase in the diagnostic yield in patients with apparently idiopathic spermatogenic failure. Asian, J. Androl. 2020. [CrossRef]

16. Cannarella, R.; Condorelli, R.A.; Duca, Y.; La Vignera, S.; Calogero, A.E. New insights into the genetics of spermatogenic failure: A review of the literature. Qual. Life Res. 2019, 138, 125-140. [CrossRef]

17. Amberger, J.S.; Bocchini, C.A.; Schiettecatte, F.J.M.; Scott, A.F.; Hamosh, A. OMIM.org: Online Mendelian Inheritance in Man (OMIM®), an online catalog of human genes and genetic disorders. Nucleic Acids Res. 2015, 43, D789-D798. [CrossRef]

18. Bracke, A.; Peeters, K.; Punjabi, U.; Hoogewijs, D.; Dewilde, S. A search for molecular mechanisms underlying male idiopathic infertility. Reprod. Biomed. Online 2018, 36, 327-339. [CrossRef]

19. Cariati, F.; Savarese, M.; D'Argenio, V.; Salvatore, F.; Tomaiuolo, R. The SEeMORE strategy: Single-tube electrophoresis analysis-based genotyping to detect monogenic diseases rapidly and effectively from conception until birth. Clin. Chem. Lab. Med. 2017, 56, 40-50. [CrossRef]

20. Griffin, D.K.; Ogur, C. Chromosomal analysis in IVF: Just how useful is it? Reproduction 2018, 156, F29-F50. [CrossRef]

21. Cariati, F.; D'Argenio, V.; Tomaiuolo, R. The evolving role of genetic tests in reproductive medicine. J. Transl. Med. 2019, 17, 267. [CrossRef] [PubMed]

22. Cooper, T.G.; Noonan, E.; Von Eckardstein, S.; Auger, J.; Baker, H.W.G.; Behre, H.M.; Haugen, T.B.; Kruger, T.; Wang, C.; Mbizvo, M.T.; et al. World Health Organization reference values for human semen characteristics*ł. Hum. Reprod. Updat. 2009, 16, 231-245. [CrossRef] [PubMed]

23. Krausz, C.; Riera-Escamilla, A. Genetics of male infertility. Nat. Rev. Urol. 2018, 15, 369-384. [CrossRef] [PubMed]

24. Oud, M.S.; Volozonoka, L.; Smits, R.M.; Vissers, L.E.L.M.; Ramos, L.; Veltman, J.A. A systematic review and standardized clinical validity assessment of male infertility genes. Hum. Reprod. 2019, 34, 932-941. [CrossRef]

25. Kusz-Zamelczyk, K.; Tomczyk, L.; Sajek, M.P.; Spik, A.; Latos-Bielenska, A.; Jedrzejczak, P.; Pawelczyk, L.; Jaruzelska, J. The highly conserved NANOS2 protein: Testis-specific expression and significance for the human male reproduction. Mol. Hum. Reprod. 2009, 15, 165-171. [CrossRef]

26. Jedidi, I.; Ouchari, M.; Yin, Q. Autosomal single-gene disorders involved in human infertility. Saudi, J. Biol. Sci. 2017, 25, 881-887. [CrossRef]

27. Robay, A.; Abbasi, S.; Akil, A.; El-Bardisi, H.; Arafa, M.; Crystal, R.G.; Crystal, R.G. A systematic review on the genetics of male infertility in the era of next-generation sequencing. Arab. J. Urol. 2018, 16, 53-64. [CrossRef]

28. Yang, F.; Silber, S.; Leu, N.A.; Oates, R.D.; Marszalek, J.D.; Skaletsky, H.; Brown, L.G.; Rozen, S.G.; Page, D.C.; Wang, P.J. TEX 11 is mutated in infertile men with azoospermia and regulates genome-wide recombination rates in mouse. EMBO Mol. Med. 2015, 7, 1198-1210. [CrossRef]

29. Merveille, A.-C.; Davis, E.E.; Becker-Heck, A.; Legendre, M.; Amirav, I.; Bataille, G.; Belmont, J.; Beydon, N.; Billen, F.; Clément, A.; et al. CCDC39 is required for assembly of inner dynein arms and the dynein regulatory complex and for normal ciliary motility in humans and dogs. Nat. Genet. 2010, 43, 72-78. [CrossRef]

30. Bartels, C.F.; Scacheri, C.; White, L.; Scacheri, P.C.; Bale, S. Mutations in the CHD7 Gene: The Experience of a Commercial Laboratory. Genet. Test. Mol. Biomark. 2010, 14, 881-891. [CrossRef] [PubMed] 
31. Philibert, P.; Zenaty, D.; Lin, L.; Soskin, S.; Audran, F.; Léger, J.; Achermann, J.C.; Sultan, C. Mutational analysis of steroidogenic factor 1 (NR5a1) in 24 boys with bilateral anorchia: A French collaborative study. Hum. Reprod. 2007, 22, 3255-3261. [CrossRef] [PubMed]

32. Mallepaly, R.; Butler, P.R.; Herati, A.S.; Lamb, D.J.; Vogt, P. Genetic Basis of Male and Female Infertility. Genet. Hum. Infertil. 2017, 21, 1-16. [CrossRef]

33. Mobasheri, M.B.; Babatunde, K. Testicular miRNAs in relation to spermatogenesis, spermatogonial stem cells and cancer/testis genes. Sci. Afr. 2019, 3, e00067. [CrossRef]

34. Xiong, H.Y.; Alipanahi, B.; Lee, L.J.; Bretschneider, H.; Merico, D.; Yuen, R.K.C.; Hua, Y.; Gueroussov, S.; Najafabadi, H.S.; Hughes, T.R.; et al. The human splicing code reveals new insights into the genetic determinants of disease. Science 2014, 347, 1254806. [CrossRef]

35. Hopps, C.; Mielnik, A.; Goldstein, M.; Palermo, G.; Rosenwaks, Z.; Schlegel, P. Detection of sperm in men with $\mathrm{Y}$ chromosome microdeletions of the AZFa, AZFb and AZFc regions. Hum. Reprod. 2003, 18, 1660-1665. [CrossRef]

36. Neto, F.T.L.; Bach, P.V.; Najari, B.B.; Li, P.S.; Goldstein, M. Genetics of Male Infertility. Curr. Urol. Rep. 2016, 17, 1-12. [CrossRef]

37. Miyamoto, T.; Minase, G.; Shin, T.; Ueda, H.; Okada, H.; Sengoku, K. Human male infertility and its genetic causes. Reprod. Med. Biol. 2017, 16, 81-88. [CrossRef]

38. Adelman, C.A.; Petrini, J.H. ZIP4H (TEX11) Deficiency in the Mouse Impairs Meiotic Double Strand Break Repair and the Regulation of Crossing Over. PLoS Genet. 2008, 4, e1000042. [CrossRef]

39. Yatsenko, A.N.; Georgiadis, A.P.; Röpke, A.; Berman, A.J.; Jaffe, T.; Olszewska, M.; Westernströer, B.; Sanfilippo, J.; Kurpisz, M.; Rajkovic, A.; et al. X-Linked TEX11 Mutations, Meiotic Arrest, and Azoospermia in Infertile Men. N. Engl. J. Med. 2015, 372, 2097-2107. [CrossRef]

40. Zheng, K.; Yang, F.; Wang, P.J. Regulation of male fertility by X-linked genes. J. Androl. 2009, 31, 79-85. [CrossRef]

41. Sha, Y.; Zheng, L.; Ji, Z.; Mei, L.; Ding, L.; Lin, S.; Wang, X.; Yang, X.; Li, P. A novel TEX11 mutation induces azoospermia: A case report of infertile brothers and literature review. BMC Med. Genet. 2018, 19, 63. [CrossRef]

42. Antony, D.; Becker-Heck, A.; Zariwala, M.A.; Schmidts, M.; Onoufriadis, A.; Forouhan, M.; Wilson, R.; Taylor-Cox, T.; Dewar, A.; Jackson, C.; et al. Mutations inCCDC39andCCDC40are the Major Cause of Primary Ciliary Dyskinesia with Axonemal Disorganization and Absent Inner Dynein Arms. Hum. Mutat. 2013, 34, 462-472. [CrossRef]

43. Balasubramanian, R.; Crowley, W.F. Reproductive endocrine phenotypes relating toCHD7mutations in humans. Am. J. Med. Genet. Part. C Semin Med. Genet. 2017, 175, 507-515. [CrossRef]

44. Pauli, S.; Von Velsen, N.; Burfeind, P.; Steckel, M.; Manz, J.; Buchholz, A.; Borozdin, W.; Kohlhase, J. CHD7 mutations causing CHARGE syndrome are predominantly of paternal origin. Clin. Genet. 2011, 81, 234-239. [CrossRef]

45. Bouazoune, K.; Kingston, R.E. Chromatin remodeling by the CHD7 protein is impaired by mutations that cause human developmental disorders. Proc. Natl. Acad. Sci. USA 2012, 109, 19238-19243. [CrossRef]

46. Morohashi, K.; Honda, S.; Inomata, Y.; Handa, H.; Omura, T. A common trans-acting factor, Ad4-binding protein, to the promoters of steroidogenic P-450s. J. Biol. Chem. 1992, 267, 17913-17919.

47. Lin, L.; Achermann, J.C. Steroidogenic factor-1 (SF-1, Ad4BP, NR5A1) and disorders of testis development. Sex. Dev. 2008, 2, 200-209. [CrossRef]

48. Sekido, R.; Lovell-Badge, R. Sex determination involves synergistic action of SRY and SF1 on a specific Sox9 enhancer. Nat. Cell Biol. 2008, 453, 930-934. [CrossRef]

49. Bashamboo, A.; Ferraz-De-Souza, B.; Lourenço, D.; Lin, L.; Sebire, N.J.; Montjean, D.; Bignon-Topalovic, J.; Mandelbaum, J.; Siffroi, J.-P.; Christin-Maitre, S.; et al. Human Male Infertility Associated with Mutations in NR5A1 Encoding Steroidogenic Factor 1. Am. J. Hum. Genet. 2010, 87, 505-512. [CrossRef]

50. Ferlin, A.; Rocca, M.S.; Vinanzi, C.; Ghezzi, M.; Di Nisio, A.; Foresta, C. Mutational screening of NR5A1 gene encoding steroidogenic factor 1 in cryptorchidism and male factor infertility and functional analysis of seven undescribed mutations. Fertil. Steril. 2015, 104, 163-169.e1. [CrossRef]

51. Rocca, M.S.; Ortolano, R.; Menabò, S.; Baronio, F.; Cassio, A.; Russo, G.; Balsamo, A.; Ferlin, A.; Baldazzi, L. Mutational and functional studies on NR5A1 gene in 46,XY disorders of sex development: Identification of six novel loss of function mutations. Fertil. Steril. 2018, 109, 1105-1113. [CrossRef] [PubMed] 
52. Harper, J.C.; Aittomäki, K.; Borry, P.; Cornel, M.C.; De Wert, G.; Dondorp, W.; Geraedts, J.; Gianaroli, L.; Ketterson, K.; Liebaers, I.; et al. Recent developments in genetics and medically assisted reproduction: From research to clinical applications. Eur. J. Hum. Genet. 2017, 26, 12-33. [CrossRef] [PubMed]

53. Mau-Holzmann, U. Somatic chromosomal abnormalities in infertile men and women. Cytogenet. Genome Res. 2005, 111, 317-336. [CrossRef] [PubMed]

54. Kim, J.-W.; Chang, E.M.; Song, S.H.; Park, S.H.; Yoon, T.K.; Shim, S.H. Complex chromosomal rearrangements in infertile males: Complexity of rearrangement affects spermatogenesis. Fertil. Steril. 2011, 95, 349-352. [CrossRef] [PubMed]

55. Punab, M.; Poolamets, O.; Paju, P.; Vihljajev, V.; Pomm, K.; Ladva, R.; Korrovits, P.; Laan, M. Causes of male infertility: A 9-year prospective monocentre study on 1737 patients with reduced total sperm counts. Hum. Reprod. 2016, 32, 18-31. [CrossRef]

56. GeneReviews ${ }^{\circledR}$ [Internet]; Adam, M.P.; Ardinger, H.H.; Pagon, R.A.; Wallace, S.E.; Bean, L.J.H.; Stephens, K.; Amemiya, A. (Eds.) University of Washington: Seattle, WA, USA, 1993-2020.

57. Mattassi, R.; Manara, E.; Colombo, P.G.; Manara, S.; Porcella, A.; Bruno, G.; Bruson, A.; Bertelli, M. Variant discovery in patients with Mendelian vascular anomalies by next-generation sequencing and their use in patient clinical management. J. Vasc. Surg. 2018, 67, 922-932.e11. [CrossRef]

58. Marceddu, G.; Dallavilla, T.; Guerri, G.; Zulian, A.; Marinelli, C.; Bertelli, M. Analysis of machine learning algorithms as integrative tools for validation of next generation sequencing data. Eur. Rev. Med. Pharmacol. Sci. 2019, 23, 8139-8147.

59. Richards, S.; Aziz, N.; Bale, S.; Bick, D.; Das, S.; Gastier-Foster, J.; Grody, W.W.; Hegde, M.; Lyon, E.; Spector, E.; et al. ACMG Laboratory Quality Assurance Committee. Standards and guidelines for the interpretation of sequence variants: A joint consensus recommendation of the American College of Medical Genetics and Genomics and the Association for Molecular Pathology. Genet. Med. 2015, 17, 405-424.

Publisher's Note: MDPI stays neutral with regard to jurisdictional claims in published maps and institutional affiliations. 